\title{
PENDEKATAN INKUIRI-KONTEKSTUAL BERBASIS TEKNOLOGI INFORMASI UNTUK MENINGKATKAN KETERAMPILAN BERFIKIR KRITIS MAHASISWA
}

\author{
Ai Mahmudatussa'adah \\ Jurusan Pendidikan Kesejahteraan Keluarga FPTK UPI, \\ Jl. Dr. Setiabudhi No. 207 Bandung 40154 \\ aims_upi@yahoo.co.id
}

\begin{abstract}
Abstrak: Bahan tambahan makanan merupakan salah satu topik bahasan yang terdapat dalam mata kuliah kimia makanan. Sudah menjadi rahasia umum, kimia merupakan salah satu mata kuliah yang sulit dimengerti karena bersifat abstrak walaupun manfaat nyatanya banyak dan sangat berhubungan langsung dengan aplikasi kehidupan sehari-hari. Penguasaan kimia makanan mahasiswa rata-rata di bawah $60 \%$. Hasil penelitian didapatkan bahwa pendekatan inkuiri-kontekstual berbasis informasi teknologi topik food additive dapat meningkatkan keterampilan berfikir kritis mahasiswa. Peningkatan nilai pretest ke postes dialami oleh semua sampel dengan nilai N-Gain yang berbeda-beda. Sebagian besar (59\%) berada pada kategori sedang, $20 \%$ pada kategori tinggi dan sebagian kecil (11\%) berada pada kategori rendah. Pendekatan inkuiri-kontekstual berbasis informasi teknologi topik food additive menjadikan mahasiswa lebih aktif dan semangat dalam belajar.
\end{abstract}

Kata kunci: inkuiri-kontekstual, teknologi informasi, bahan tambah makanan

\begin{abstract}
Food additive is one of the topics included in the food chemistry course. Despite its benefits which are directly related to everyday life applications, it is common knowledge that the chemistry is one of the subjects that are difficult to understand for its abstraction. Students' average mastery of food chemistry is below $60 \%$. The study found that information technology-based contextual inquiry approach to topic of food additives can improve students' critical thinking skills. Increase in scores from pretest to posttest is experienced by all samples with different N-Gain values. The majority (59\%) is in medium category, $20 \%$ in high category and a fraction (11\%) is in low category. Information technology-based contextual inquiry approach to the topic of food additives makes students more active and increases learning enthusiasm.
\end{abstract}

Keywords: contextual inquiry, information technology, food additive

\section{PENDAHULUAN}

Bahan tambahan makanan atau food additive merupakan salah satu topik bahasan yang terdapat dalam mata kuliah kimia makanan (BG 126). Kimia makanan merupakan salah satu mata kuliah bidang studi yang harus diambil mahasiswa S-1 program studi Pendidikan Pendidikan Tata Boga di semester 2 dengan beban 2 sks. Mahasiswa S-1 program studi Pendidikan Pendidikan Tata Boga umumnya berasal dari SMA (IPA, IPS, Bahasa) dan SMK yang memiliki pengetahuan dasar mengenai kimia cukup lemah (terbukti dari tanya jawab di awal perkuliahan kimia makanan). Food additive merupakan salah satu topik bahasan yang mempunyai beban muatan materi (sub pokok bahasan) cukup banyak, sedangkan waktu yang

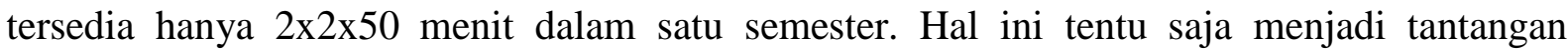
tersendiri untuk dosen pengampu mata kuliah untuk lebih kreatif menciptakan kondisi pembelajaran yang menyenangkan dan menggunakan metode pembelajaran yang tepat untuk mencapai tujuan pembelajaran. 
Sudah menjadi rahasia umum, kimia merupakan salah satu mata kuliah yang sulit dimengerti karena bersifat abstrak walaupun manfaat nyatanya banyak dan sangat berhubungan langsung dengan aplikasi kehidupan sehari-hari. Mahasiswa Prodi Pendidikan Tata Boga khususnya, yang bergerak dalam masalah kuliner, mempunyai tanggung jawab untuk menghasilkan produk makanan dan minuman yang tidak saja enak secara rasa tapi harus aman dan bergizi untuk dikonsumsi. Pengetahuan mengenai food additive sangat diperlukan oleh mahasiswa Prodi Pendidikan Tata Boga seiring dengan munculnya penyalahgunaan pengawet, perisa, pengenyal, pewarna seperti formalin, boraks, rodhamin B, dll, yang sebenarnya bukan untuk tambahan makanan, tetapi malah dipergunakan untuk makanan.

Selama ini proses pembelajaran kimia makanan di prodi Pendidikan Tata Boga, masih disampaikan secara konvensional (ceramah). Mahasiswa kurang terlibat langsung secara aktif dalam proses pembelajaran. Dominasi dosen dalam proses pembelajaran menyebabkan mahasiswa lebih banyak menunggu sajian dari dosen, daripada mencari dan menemukan sendiri pengetahuan, keterampilan, serta sikap yang mereka butuhkan. Hasil belajarpun masih sangat rendah. Penguasaan kimia makanan mahasiswa rata-rata di bawah 60\% (terlihat dari hasil evaluasi UTS dan UAS). Mahasiswa masih belum dapat menghubungkan atau mengaflikasikan pengetahuan kimianya dengan kehidupan nyata yang mereka hadapi baik di kampus ataupun di masyarakat (kontekstual). Seiring dengan berkembangnya kemajuan teknologi informasi, maka berbagai macam informasi aktual yang berhubungan dengan food additeve makin mudah untuk diakses. Dengan demikian, dalam penelitian ini akan dilakukan pendekatan inkuiri-kontekstual berbasis informasi teknologi pada topik food additive untuk meningkatkan keterampilan berfikir kritis mahasiswa.

Rumusan masalah dalam penelitian ini adalah apakah dengan pendekatan inkuirikontekstual berbasis teknologi informasi topik food additive dapat meningkatkan kemampuan berfikir kritis mahasiswa? Tujuan penelitian secara umum yaitu untuk menemukan model pembelajaran kimia makanan yang dapat digunakan untuk meningkatkan keterampilan berfikir kritis mahasiswa pada pokok bahasan food additive. Tujuan penelitian secara khusus untuk mengetahui karakteristik dari model pembelajaran yang digunakan dalam penelitian ini, untuk mengetahui pengaruh pendekatan inkuiri-kontekstual berbasis teknologi informasi terhadap peningkatan keaktifan mahasiswa, untuk mengetahui pengaruh pendekatan inkuirikontekstual berbasis teknologi informasi terhadap keterampilan berfikir kritis mahasiswa, dan untuk mengetahui pendapat mahasiswa terhadap model pembelajaran yang diterapkan.

Manfaat yang diharapkan dari hasil penelitian ini adalah memberikan alternatif model pembelajaran kimia makanan pada topik food additive yang dapat meningkatkan keterampilan 
berfikir kritis mahasiswa; meningkatkan keterlibatan dan ketertarikan mahasiswa dalam mempelajari kimia makanan, khususnya topik food additive, melalui kegiatan penemuan yang bersifat kontekstual berbasis teknologi informasi; memberikan referensi bagi peneliti lain dalam mengembangkan model-model pembelajaran kimia makanan.

Carin (1985), berpendapat inkuiri adalah suatu perluasan proses discovery yang digunakan dalam cara yang lebih dewasa. Discovery adalah suatu proses mental dimana anak atau individu mengasimilasi konsep dan prinsip. Suchman (1992), mengembangkan model pembelajaran dengan pendekatan inquiri. Model pembelajaran ini melatih siswa dalam suatu proses untuk menginvestigasi dan menjelaskan suatu fenomena yang tidak biasa. Model pembelajaran ini mengajak siswa untuk melakukan hal yang serupa seperti para ilmuwan dalam usaha mereka untuk mengorganisir pengetahuan dan membuat prinsip.

Inkuiri bukan hanya metode atau pendekatan pembelajaran, melainkan juga sebuah filosofi belajar. Mahasiswa atau peserta didik dilatih untuk selalu bertanya kemudian menentukan strategi atau cara menjawab, menganalisis dan akhirnya memukan jawaban dari pertanyaannya. Model pembelajaran inkuiri dimulai dengan suatu kejadian yang menimbulkan keingintahuan mahasiswa atau peserta didik. Hal ini perlu dilakukan oleh guru, dosen atau pendidik agar siswa termotivasi dan menimbulkan keinginannya untuk menyelidiki data yang ada dan merangkaikan data yang diperoleh satu sama lain menurut asumsi yang baru dan mereka akan mengorganisasi pengetahuannya.

Pendekatan inkuiri memang tidak dapat dipisahkan dari pendekatan "pemecahan masalah". Untuk menerapkan pendekatan ini dosen, guru, atau pendidik harus berpikir dan berperilaku yang memfasilitasi mahasiswa/peserta didik untuk dapat membuat identifikasi apa yang akan dipelajari. Dosen guru, atau pendidik membantu mahasiswa dalam membuat pertanyaan, menentukan strategi mengumpulkan informasi dan mengolah informasi. Pendekatan ini memerlukan dosen, guru, atau pendidik yang kreatif dalam menyusun pembelajaran dan bekerja dengan rencana yang baik. Ketika mahasiswa belajar, mereka sudah mempunyai target yang jelas. Pendekatan ini memberikan tantangan yang cukup baik bagi pendidik ataupun peserta didik. Dosen dan mahasiswa akhirnya berada dalam perspektif yang sama yaitu menjadi pembelajar. Bahkan pada situasi tertentu guru dan siswa akan belajar tentang hal yang sama.

Model pembelajaran inkuiri akan lebih menyadarkan siswa tentang proses penyelidikannya dan belajar tentang prosedur ilmiah secara langsung. Hilda (2002) menyatakan bahwa pendekatan belajar dengan model inkuiri terdiri atas lima tahapan, yaitu:

1. Tahap penyajian masalah atau menghadapkan siswa pada situasi yang memacu keingintahuan mahasiswa/peserta didik. Pada tahap ini guru membawa situasi masalah 
dan menentukan prosedur inkuiri kepada siswa (berbentuk pertanyaan yang hendaknya dijawab ya/tidak). Permasalahan yang diajukan adalah masalah yang sederhana yang dapat menimbulkan rasa ingin tahu peserta didik. Hal ini diperlukan untuk memberikan pengalaman kreasi pada siswa, tetapi sebaiknya didasarkan pada ide yang sederhana, yang dekat dengan lingkungan peserta didik.

2. Tahap pengumpulan dan verifikasi data. Peserta didik mengumpulkan data informasi tentang peristiwa yang mereka lihat atau alami.

3. Tahap eksperimen. Pada tahap ini peserta didik melakukan eksperimen untuk mengeksplorasi dan menguji secara langsung. Eksplorasi mengubah segala sesuatu untuk mengetahui pengaruhnya, tidak selalu diarahkan oleh suatu teori atau hipotesis. Pengujian secara langsung terjadi ketika peserta didik menguji hipotesis atau teori. Pada tahap ini guru berperan untuk mengendalikan siswa bila mengasumsikan suatu variabel yang telah disangkalnya, padahal pada kenyataannya tidak. Peran pendidik lainnya pada tahap ini adalah memperluas informasi yang telah diperoleh. Selama verifikasi peserta didik boleh mengajukan pertanyaan tentang objek, ciri, kondisi, dan peristiwa.

4. Tahap mengorganisasikan data dan merumuskan penjelasan. Pada tahap ini pendidi mengajak peserta didik merumuskan penjelasan. Kemungkinan besar akan ditemukan peserta didik yang mendapatkan kesulitan dalam mengemukakan informasi yang diperoleh menjadi uraian penjelasan. Peserta didik yang demikian didorong untuk dapat memberi penjelasan yang tidak begitu mendetail.

5. Tahap mengadakan analisis terhadap proses inkuiri. Pada tahap ini peserta didik diminta untuk menganalisis pola penemuan mereka. Mereka boleh menentukan pertanyaan yang lebih efektif, pertanyaan yang produktif atau tipe informasi yang dibutuhkan dan tidak diperoleh. Tahap ini akan menjadi penting apabila dilaksanakan pendekatan model inkuiri dan dicoba memperbaiki secara sistematis dan independen. Konflik yang dialami peserta didik saat melihat suatu kejadian yang menurut pandangannya tidak umum dapat menuntun partisipasi aktif dalam penyelidikan secara ilmiah.

Menurut Joyce dan Weil (1996), model pembelajaran dikelompokkan menjadi empat jenis, yang salah satunya adalah model pemrosesan informasi seperti model pembelajaran inkuiri. Hofstein dan Woldberg (2005), menyatakan bahwa pembelajaran inkuiri melatih siswa untuk belajar sains mulai dari menemukan permasalahan, menyusun hipotesis, merencanakan eksperimen, menganalisa data, dan menggambarkan kesimpulan tentang masalah ilmiah. Pembelajaran inkuiri menuntut adanya eksperimen atau percobaan di laboratorium. Namun karena tidak semua institusi mempunyai laboratorium, dan harga 
pereaksi yang mahal maka dengan demikian pembelajaran inkuiri dapat dilakukan dengan menggunakan teknologi informasi.

Perkembangan teknologi informasi makin pesat dan sangat diminati oleh berbagai kalangan karena berbagai kemudahan yang ditawarkan. Contoh teknologi informasi yang berkembang sangat pesat saat ini adalah hand phone, komputer dan internet. Komputer dan internet sering dijadikan sebagai media untuk melaksanakan pendidikan. Teknologi informasi dapat diartikan sebagai sejumlah kumpulan sistem informasi, pengguna (user), serta manajemennya yang terorganisir (Turban,1999). Teknologi informasi diartikan sebagai teknologi informatika yang mampu mendukung percepatan dan meningkatkan kualitas informasi, serta percepatan arus informasi ini tidak mungkin dibatasi ruang dan waktu. Teknologi informasi internet memberikan kemudahan kepada siapapun untuk mengakses berbagai informasi secara aktual. Teknologi informasi adalah teknologi yang menggabungkan komputer dengan jalur komunikasi berkecepatan tinggi yang membawa data, suara, dan video (Kadir dan Triwahyuni, 2003).

Menurut Pedoman Kusus Pengembangan Silabus dan Penilaian Mata Pelajaran Kimia, Depdiknas (2003), bahwa pengalaman belajar tidak hanya diperuntukan agar siswa dapat menguasai kompetensi dasar yang telah ditentukan, tetapi hendaknya memuat kecakapan hidup (life skill). Kecakapan hidup merupakan kecakapan yang dimiliki seseorang untuk berani menghadapi problem hidup dan kehidupan dengan wajar, tidak tertekan, kemudian secara proaktif dan kreatif mencari serta menemukan solusi sehingga mampu mengatasinya. Menurut Peraturan Mendiknas No 23 Tahun 2006, tujuan pembelajaran mata pelajaran ilmu pengetahuan dan teknologi adalah mengembangkan logika, kemampuan berfikir dan analisis mahasiswa. Salah satu dari kemampuan berfikir yang penting dimiliki oleh mahasiswa adalah berfikir kritis.

Berfikir kritis menggunakan dasar proses berfikir untuk menganalisis argumen dan memunculkan wawasan terhadap tiap makna dan interpretasi, untuk mengembangkan pola penalaran yang kohesif dan logis, memahami asumsi dan bias yang mendasari tiap posisi (Liliasari, 2005). Berfikir kritis merupakan cara berfikir reflektif yang masuk akal atau berdasarkan nalar yang difokuskan untuk menentukan apa yang harus diyakini dan apa yang harus dilakukan. Indikator keterampilan berfikir kritis dibagi menjadi lima kelompok: memberikan penjelasan sederhana, membangun keterampilan dasar, menyimpulkan, membuat penjelasan lebih lanjut, serta mengatur strategi dan taktik. Menurut Dimyati dan Mudjiono (2002), belajar merupakan tindakan dan perilaku siswa yang kompleks. Sebagai tindakan, maka belajar hanya dialami oleh siswa sendiri. Siswa adalah penentu terjadinya atau tidak terjadinya proses belajar. Belajar adalah suatu perilaku. 
Bahan tambahan pangan (BTP) adalah bahan atau campuran bahan yang secara alami bukan merupakan bagian dari bahan baku pangan, tetapi ditambahkan ke dalam pangan untuk mempengaruhi sifat atau bentuk bahan pangan. BTP ditambahkan untuk memperbaiki karakter pangan agar kualitasnya meningkat. Pemakaian BTP merupakan salah satu langkah teknologi yang diterapkan oleh industri pangan berbagai skala. Sebagaimana langkah teknologi lain, maka risiko kesalahan dan penyalahgunaan tidak dapat dikesampingkan. BTP pada umumnya merupakan bahan kimia yang telah diteliti dan diuji lama sesuai dengan kaidah ilmiah yang ada. Pemerintah telah mengeluarkan aturan pemakaian BTP secara optimal.

Dalam kehidupan sehari-hari BTP sudah digunakan secara umum oleh masyarakat. Kenyataannya masih banyak produsen makanan yang menggunakan bahan tambahan yang berbahaya bagi kesehatan. Efek dari bahan tambahan beracun tidak dapat langsung dirasakan, tetapi secara perlahan dan pasti dapat menyebabkan sakit. Penyimpangan atau pelanggaran mengenai penggunaan BTP yang sering dilakukan oleh produsen pangan, yaitu: 1) menggunakan bahan tambahan yang dilarang penggunaannya untuk makanan; 2) menggunakan BTP melebihi dosis yang diizinkan. Penggunaan bahan tambahan yang beracun atau BTP yang melebihi batas akan membahayakan kesehatan masyarakat, dan berbahaya bagi pertumbuhan generasi yang akan datang. Karena itu, produsen pangan perlu mengetahui peraturan yang telah dikeluarkan oleh pemerintah mengenai penggunaan BTP.

Secara khusus tujuan penggunaan BTP di dalam pangan adalah untuk: 1) mengawetkan makanan dengan mencegah pertumbuhan mikroba perusak pangan atau mencegah terjadinya reaksi kimia yang dapat menurunkan mutu pangan; 2) membentuk makanan menjadi lebih baik, renyah dan lebih enak di mulut, 3) memberikan warna dan aroma yang lebih menarik sehingga menambah selera, 4) meningkatkan kualitas pangan, dan 5) menghemat biaya. Produsen produk pangan menambahkan BTP dengan berbagai tujuan, misalnya membantu proses pengolahan, memperpanjang masa simpan, memperbaiki penampilan dan cita rasa, serta pengaturan keseimbangan gizi.

Berdasarkan fungsinya, menurut peraturan Menkes No. 235 tahun 1979, BTP dapat dikelompokan menjadi 14 yaitu: antioksidan, antikempal, pengasam, penetral dan pendapar, enzim, pemanis buatan, pemutih dan pematang, penambah gizi, pengawet, pengemulsi, pemantap dan pengental, pengeras, pewarna sintetis dan alami, penyedap rasa dan aroma, dan sekuestran. BTP dikelompokan berdasarkan tujuan penggunaanya di dalam pangan. Pengelompokkan BTP yang diizinkan digunakan pada makanan dapat digolongkan sebagai pewarna, pemanis buatan, pengawet, antioksidan, antikempal, penyedap dan penguat rasa 
serta aroma, pengatur keasaman, pemutih dan pamatang tepung, pengemulsi, pemantap dan pengental, pengeras, sekuestran, humektan, enzim dan penambah gizi.

BTP dapat berupa ekstrak bahan alami atau hasil sintesis kimia. Bahan yang berasal dari alam umumnya tidak berbahaya, sementara BTP artifisial atau sintetik mempunyai risiko terhadap kesehatan jika disalahgunakan pemakaiannya. Produsen pangan skala rumah tangga atau industri kecil memakai Bahan tambahan yang dinyatakan berbahaya bagi kesehatan karena alasan biaya. Tidak jarang, produk pangan ditambahkan zat yang bukan untuk makanan tapi untuk industri lain, misalnya untuk tekstil dan cat. Badan POM (Pengawas Obat dan Makanan) menemukan banyak produk yang mengandung formalin. Formalin bersifat desinfektan, pembunuh hama, dan sering dipakai untuk mengawetkan mayat. Pewarna tekstil seperti Rhodamin B sering pula ditemukan pada kerupuk dan terasi. Mengkonsumsi makanan yang mengandung formalin atau Rhodamin dapat menyebabkan kerusakan organ dalam tubuh dan kanker.

Bahan tambahan yang dilarang oleh BPOM, melalui Permenkes No. 722/Menkes/Per/IX/88 adalah asam borat, asam salisilat, dietilpirokarbonat, dulsin, kalium klorat, kloramfenol, minyak nabati yang dibrominasi, nitrofurazon, dan formalin.

\section{METODE}

Metode penelitian yang digunakan adalah metode kuasi eksperimen dengan rancangan penelitian one group pretest-postest design. Penelitian ini adalah bertujuan untuk meningkatkan kualitas proses pembelajaran dan hasil pembelajaran kimia makanan. Penelitian ini menggunakan alur penelitian dimulai dengan perencanaan, pelaksanaan dan evaluasi. Penelitian ini dilaksanakan di Program Studi Pendidikan Tata Boga Jurusan PKK FPTK UPI. Populasi penelitian ini adalah mahasiswa yang mengikuti mata kuliah kimia makanan semester 2 (genap) tahun ajaran 2009/2010 sebanyak satu kelas dengan jumlah mahasiswa sekitar 40 orang. Instrumen penelitian ini menggunakan soal tes dan lembaran observasi. Soal tes digunakan untuk mendapatkan data tentang peningkatan kemampuan berfikir kritis mahasiswa. Lembar observasi digunakan untuk melihat proses pembelajaran.

\section{HASIL PENELITIAN}

Hasil penelitian ini didapatkan nilai rata-rata sampel meningkat dari pretes ke postes. Hal ini menunjukkan model pembelajaran inkuiri kontekstual berbasis teknologi informasi dapat meningkatkan hasil belajar siswa. Pembelajaran dengan pendekatan ikuiri kontekstual memberikan kesempatan kepada mahasiswa untuk berperan aktif dalam memahami materi khususnya food additive. Mahasiswa diposisikan sebagai manusia dewasa yang sudah dapat 
berfikir dan bertindak memecahkan permasalahan yang ada dihadapannya. Mahasiswa dapat menggunakan semua panca indranya untuk dapat memahami materi. Adanya pemanfaatan panca indera secara terintegrasi dapat memberikan pemahaman yang lebih lama pada mahasiswa.

Tabel 1. Nilai N-Gain

\begin{tabular}{ccc}
\hline N-Gain & Frekuensi & Persentase (\%) \\
\hline Rendah & 5 & 1 \\
\hline Sedang & 26 & 59 \\
\hline Tinggi & 9 & 20 \\
\hline
\end{tabular}

Nilai N-Gain yang diperoleh bahwa peningkatan hasil belajar siswa relatif cukup besar. Hal ini menunjukkan bahwa penggunaan pendekatan inquiri- kontekstual dalam pokok bahasan food additive dapat meningkatkan hasil belajar dan keterampilan berfikir kritis mahasiswa. Dengan pendekatan inquiri-kontekstual mahasiswa diposisikan sebagai mahasiswa yang aktif, dituntut untuk terus aktif menggunakan semua panca inderanya untuk bersama-sama mencapai tujuan pembelajaran yang sudah ditetapkan.

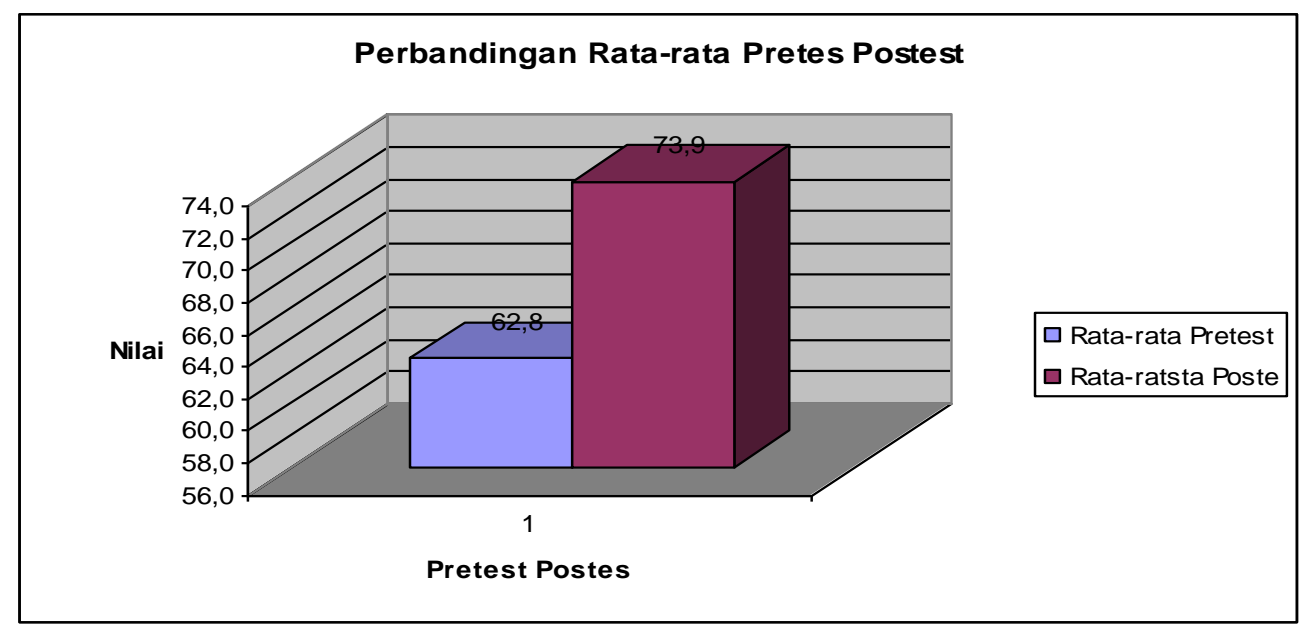

Gambar 1. Perbandingan Nilai Pretes dengan Postes

\section{PEMBAHASAN}

Salah satu tujuan pembelajaran kimia makanan adalah untuk meningkatkan pengetahuan mahasiswa mengenai komponen kimia yang terdapat dalam makanan serta dapat mengaplikasikan segala pengetahuannya dalam kehidupan sehari-hari. Mahasiswa diharapkan dapat berfikir kritis terutama dengan melihat kecenderungan minat masyarakat terhadap makanan berkualitas (bergizi, enak dan menarik), disatu sisi ada sebagian produsen makanan yang nakal ingin menampilkan makanan yang menarik dan tahan lama namun tetap murah, sehingga mereka menambahkan bahan-bahan yang tidak diperuntukkan untuk makanan 
(pewarna tekstil, cat, boraks) di dalam produk makanan yang mereka buat. Mahasiswa pendidikan tata boga khususnya yang sekarang dan nanti akan sangat berhubungan terus dengan makanan baik sebagai produsen maupun konsumen harus sangat faham mengenai bahan kimia yang secara alami terdapat dalam makanan ataupun bahan makanan yang sengaja ditambahkan ke dalam bahan makanan (food additive) dengan maksud untuk meningkatkan kualitas tampilan, cita rasa, nilai gizi dan memperpanjang masa simpan. Pada kenyataannya hasil belajar mahasiswa dalam kimia makanan umumnya masih rendah, masih belum dapat berfikir kritis menganalisis fenomena di lingkungannya. Seiring dengan kemajuan ilmu dan teknologi maka untuk mengakses ilmu pengetahuan menjadi lebih mudah. Untuk menjawab permasalahan dalam penelitian ini yaitu rendahnya hasil belajar siswa, penerapan hasil belajar yang masih rendah serta daya berfikir mahasiswa yang masih belum dapat menghubungkan antara apa yang dipelajari dengan lingkungannya, maka diterapkan model pembelajaran inkuiri kontekstual berbasis teknologi informasi.

Inkuiri bukan hanya metode atau pendekatan pembelajaran, melainkan juga sebuah filosofi belajar. Mahasiswa atau mahasiswa dilatih untuk selalu bertanya kemudian menentukan strategi atau cara menjawab, menganalisis dan akhirnya memukan jawaban dari pertanyaan. Model pembelajaran inkuiri dimulai dengan suatu kejadian yang menimbulkan teka-teki kepada mahasiswa atau mahasiswa. Hal ini perlu dilakukan oleh pendidik/dosen agar siswa termotivasi dan merasa perlu untuk menyelidiki data yang ada dan merangkaikan data ini satu sama lain menurut asumsi yang baru dan mereka akan mengorganisasi pengetahuannya.

Penelitian ini dilakukan dengan menggunakan pre test dan postes dengan rancangan penelitian one group pretest-postest design. Rancangan ini dipilih karena mahasiswa sebagai sampel penelitian hanya satu kelas, sehingga tidak memungkinkan dibuat dibagi menjadi kelas kontrol. Keuntungan metode ini adalah dapat terhindar dari efek bias yang disebabkan oleh adanya pengaruh perlakuan yang berbeda. Dengan kuasi eksperimen one group pretestpostest semua sampel diberikan perlakuan yang sama.

Langkah dalam penelitian ini pertama yaitu menyiapkan bahan ajar, menyiapkan rancangan perkuliahan, media pembelajaran, dan instrumen penelitian (soal pretes dan postes, lembar observasi). Media yang digunakan adalah infocus dan kemasan beberapa makanan dan minuman ringan. Pokok bahasan food additive disampaikan dalam 2x2x50 menit. Sebelum disampaikan materi dengan pendekatan inquiri kontekstual, mahasiswa diberikan terlebih dahulu pretest untuk melihat kemampuan awal sampel. Kemudian dilakukan proses pembelajaran dengan langkah: pertama adalah penyajian masalah atau menghadapkan siswa pada permasalahan yang sedang muncul. Permasalahan yang sedang muncul saat ini adalah 
adanya penyalahgunaan bahan tambahan non pangan pada makanan, seperti penggunaan borak, Rhodamin B, dan pormalin.

Disajikan pada mahasiswa artikel infestigasi dan gambar makanan yang menggunakan bahan tambahan non pangan serta bahan tambahan pangan melalui powerpoint yang diproyeksikan dengan infocus. Pada tahap ini pendidik/peneliti membawa situasi masalah dan menentukan prosedur inkuiri kepada mahasiswa dengan mengajukan beberapa pertanyaan yang menggiring mahasiswa untuk dapat menjawab ya/tidak, yang diikuti dengan penjelasan. Permasalahan yang diajukan adalah masalah yang sederhana yang sebetulnya sering mahasiswa temui dalam kehidupan sehari-hari. Hal ini diperlukan untuk memberikan pengalaman berfikir kritis kepada mahasiswa, menanamkan kepercayaan diri untuk menanggapi suatu masalah dan sekaligus mencarikan alternatif pemecahannya. Sebaiknya permasalahan yang diajukan didasarkan pada ide yang sederhana, yang dekat dengan kehidupan mahasiswa. Bahan kimia bukanlah makhluk asing yang menakutkan asal kita tahu dan tahu cara menyikapinya dengan bijaksana.

Tahap pengumpulan dan verifikasi data. Setelah mahasiswa diberikan contoh beberapa permasalahan kemudian mahasiswa diminta untuk memperkuat segala jawabannya dengan mengumpulkan berbagai fakta dan data terutama melalui penelusuran internet. Mahasiswa diminta mengumpulkan data informasi tentang peristiwa yang mereka lihat atau alami berkaitan dengan permasalahan yang diajukan yang berkaitan dengan penggunaan food additive.

Pada tahap ini siswa melakukan eksperimen untuk mengeksplorasi dan menguji secara langsung. Setiap mahasiswa diminta untuk menganalisis satu jenis makanan dan satu jenis minuman yang menggunakan kemasan. Mahasiswa diminta untuk mengelompokkan berbagai komponen yang terdapat dalam makanan tersebut, menganalisis dan membahas kemudian mempresentasikannya. Mahasiswa diminta juga untuk mengeksplorasi makanan dan minuman yang tidak dikemas, minimal satu produk setiap mahasiswa. Eksplorasi diharapkan dapat membangkitkan sikap kritis mahasiswa yang kemudian didasari oleh suatu teori atau hipotesis. Pengujian secara langsung dapat memberikan pengalaman secara langsung. Pada tahap ini pendidik berperan untuk mengarahkan mahasiswa dan memberikan pedoman kepada mahasiswa untuk melakukan langkah ilmiah. Peran pendidik lainnya pada tahap ini adalah memperluas informasi yang telah diperoleh. Selama verifikasi siswa boleh mengajukan pertanyaan tentang objek, ciri, kondisi, dan peristiwa.

Tahap mengorganisasikan data dan merumuskan penjelasan. Pada tahap ini, mahasiswa diminta untuk memaparkan hasil investigasi, analisis dan pembahasan permasalahan yang mereka angkat. Pada tahap ini pendidik mengajak mahasiswa 
merumuskan konsep jenis, penggunaan dan pemanfaatan bahan tambahan pangan dalam pangan. Selain itu mahasiswa diminta untuk memaparkan hasil investigasi penyalahgunaan penggunaan bahan tambahan non pangan dalam makanan. Kemungkinan besar akan ditemukan mahasiswa yang mendapatkan kesulitan dalam mengemukakan informasi yang diperoleh menjadi uraian penjelasan. Mahasiswa yang demikian didorong untuk dapat memberi penjelasan sedetail yang dia mampu. Pendidik berusaha menjadi pemandu terutama bagi mahasiswa yang masih mendapatkan kesulitan.

Tahap mengadakan analisis terhadap proses inkuiri. Pada tahap ini mahasiswa diminta untuk menganalisis pola penemuan mereka. Mereka boleh menentukan pertanyaan yang lebih efektif, pertanyaan yang produktif atau tipe informasi yang dibutuhkan dan tidak diperoleh. Tahap ini akan menjadi penting apabila dilaksanakan pendekatan model inkuiri dan dicoba memperbaiki secara sistematis dan independen. Konflik yang dialami mahasiswa saat melihat suatu kejadian yang menurut pandangannya tidak umum dapat menuntun partisipasi aktif dalam penyelidikan secara ilmiah.

Seorang guru yang profesional haruslah memiliki sejumlah kompetensi yang akan mendukung terhadap tugas profesionalnya tersebut. Kompetensi ini akan tergambarkan dalam penampilan seorang pendidik ketika berada di depan kelas. Merujuk kepada UU Guru dan Dosen No.14 Tahun 2005 keempat kompetensi yang perlu dimiliki oleh seorang pendidik, yaitu: kompetensi pedagogis, profesional, kepribadian, dan sosial. Hasil observasi ditemukan hal sebagai berikut:

a. Dosen membuka pelajaran kemudian mengadakan apersepsi dengan mengajukan beberapa pertanyaan yang menjadi prasyarat pengetahuan yang harus dimiliki siswa sebelum melangkah ke pelajaran selanjutnya. Apersepsi yang dilakukan sudah baik dan berkaitan dengan pelajaran yang akan didiskusikan. Sebagian mahasiswa masih tidak berani untuk mengemukakan jawaban atau pendapat.

b. Pembagian kelompok mahasiswa sudah baik, mahasiswa dibagi menjadi 5 kelompok setiap kelompok terdiri dari 8 orang mahasiswa. Hasil pengamatan observer jumlah 8 orang dalam setiap kelompok masih terlalu banyak, sehingga ada sebagian mahasiswa yang tidak terlibat aktif dalam proses diskusi. Sebagian mahasiswa acuh tidak acuh, mereka bediskusi sendiri dengan teman terdekatnya. Dosen sebagai pasilitator kurang memperhatikan hal tersebut.

c. Interaksi antara guru dengan mahasiswa masih kaku. Dosen masih mendominasi kelas, sampel masih pasif. Hal ini disebabkan karena yang menjadi sampel adalah anak tingkat satu sehingga masih terbiasa dengan cara belajar yang harus disuapi terus. 
d. Catatan yang dibuat sampel masih belum menunjukkan kreatifitas dan ketajaman mereka dalam berfikir dan menyikapi suatu permasalahan. Sampel masih terpaku pada teoritis yang secara persis sama seperti redaksi yang mereka dapatkan dari internet.

e. Dosen masih sangat mendominasi dalam semua tahapan proses pembelajaran, dosen kurang dapat mengarahkan dan mengaktifkan mahasiswa

\section{KESIMPULAN}

Kesimpulan dari penelitian ini adalah model pembelajaran inkuiri-kontekstual berbasis teknologi informasi dapat diterapkan untuk meningkatkan kemampuan berfikir mahasiswa yang terlihat dari adanya peningkatan nilai belajar dari pretes ke postes. Peningkatan nilai pretest ke postes menunjukan ada perbaikan dan proses pembelajaran menjadi lebih aktif dan semangat belajar mahasiswa meningkat.

Dengan demikian, proses pembelajaran dengan model inkuiri kontekstual masih harus terus ditingkatkan untuk dapat lebih meningkatkan pencapaian tujuan pembelajaran. Apabila dilihat dari aktivitas belajarnya, sebagian mahasiswa masih belum terbiasa untuk mengemukakan pendapat.

\section{DAFTAR PUSTAKA}

Depdiknas. (2003). Pedoman Khusus Pengembangan Silabus dan Penilaian. Jakarta: Depdiknas.

Dimayati, dan Mudjiono. (2002). Belajar dan Pembelajaran. Jakarta: Rineka Cipta.

Hake, R. R. (1998). Interactive-engagement vs traditional methods; A six-thousand-student survey of mechanic test data for introductory physics courses. American Journal of Physics. 66, 64-67.

Hilda, Karli. (2003). 3H dalam Kurikulum Berbasis Kompetensi. Bandung: Bina Media Informasi.

Hofstein. et al. (2005). Developing students ability to ask more and better question resulting inquiry type chemistry laboratories. Journal of Science Teaching. 42 (7), 791-806.

Holbork, J. (2005). Making Chemistry Teaching Relevant. Chemical Education International. $6(1), 1-12$.

Ikhsanuddin, Liliasari, Permanasari, A. (2007). Pembelajaran Inkuiri Berbasis Teknologi Informasi untuk Meningkatkan Pemahaman Konsep dan Keterampilan Generik Sains Siswa SMA pada Topik Hidrolisis Garam. Jurnal Penelitian Pendidikan IPA. 1 (2),190198.

Joyce, Bruce and Weil. (1992). Models of Teaching (Fourth Edition). Massachussets: Allyn and Bacon Publishing Company. 
Kadir, A. \& Triwahyuni. (2003). Teknologi Informasi. Yogyakarta: Kanisius.

Liliasari (2005). Membangun Keterampilan Berfikir Manusia Indonesia Melalui Pendidikan Sains. Pidato Pengukuhan Guru Besar (Makalah). UPI Bandung. 23 Nopember 2005.

Poedjiadi, Anna. (2002). Konstruktivisme dan Pendekatan STM (Sebuah Alternatif Pembelajaran dalam Kurikulum Berbasis Kompetensi). (Makalah) pada Jurusan pendidikan kimia FPMIPA UPI Bandung: Tidak diterbitkan.

Putra, S., Hendayana, S., Mudzakir, A., (2007). Model Pembelajaran Redoks berbasis Komputer untuk Meningkatkan Pemahaman Konsep dan Keterampilan Berfikir kritis Siswa SMK. Jurnal Penelitian Pendidikan IPA. 1 (2), 163-171.

Sutisna, D.M. (2002). Upaya Meningkatkan Prestasi Belajar Ketrampilan Proses Sains Siswa Kelas II SLTP pada Pokok Bahasan Elektrostatika Melalui Eksperimen Menggunakan Model Cooperative Learning Strategis. Tesis PPS UPI Bandung: Tidak Diterbitkan.

Turban, E. Et al. (1999). Information Technology for Management: Making Connections for Strategic Advantage. ( $2^{\text {nd }}$ ed). New York: John Wiley \& Sons Inc.

Wahyudi, J.B. (1992). Teknologi Informasi dan Produksi Citra Bergerak. Jakarta: Gramedia Pustaka Utama.

Widhiyati, T., Liliasari., Setiabudhi., S. (2007). Pembelajaran Bebasis Teknologi informasi untuk Meningkatkan Pemahaman Konsep dan Keterampilan Berfikir Kritis Siswa SMK. Jurnal Penelitian Pendidikan IPA. 1 (2), 172-180. 